\title{
Oxygen dynamics in the rhizosphere of Cymodocea rotundata
}

\author{
Ole Pedersen $^{1, *}$, Jens Borum $^{1}$, Carlos M. Duarte ${ }^{2}$, Miguel D. Fortes ${ }^{3}$ \\ ${ }^{1}$ The Freshwater Biological Laboratory, University of Copenhagen, Helsingersgade 51, DK-3400 Hillered, Denmark \\ ${ }^{2}$ Centro de Estudios Avanzados de Blanes, CSIC, Camí de Santa Bárbara s/n, E-17300 Blanes, Girona, Spain \\ ${ }^{3}$ Marine Science Institute, CS, University of The Philippines, Diliman, Quezon City, The Philippines
}

\begin{abstract}
The spatial distribution of oxygen and the dynamics of the oxic microzone around roots of Cymodocea rotundata were studied using oxygen microelectrodes under constant light conditions and during light-dark transitions. Under daylight steady state conditions, oxygen was present at concentrations up to $75 \%$ of air saturation at the root surface, and the oxic microzone around the roots was $80 \mu \mathrm{m}$ thick Steady state oxygen concentrations were reached within $1.5 \mathrm{~h}$ after light-dark shifts. Under darkness, free oxygen, at about $20 \%$ of air saturation, was still present on the root surface at steady state, but the thickness of the oxic microzone shrank to $50 \mu \mathrm{m}$. The oxygen present in the rhizosphere during darkness was supplied from the water column to roots via, primarily, gas-phase diffusion in leaves and rhizomes. The oxic microzone around roots comprised about $0.5 \%$ of the total volume of the seagrass rhizosphere, and the root-mediated oxygen supply was estimated to be insignificant for the whole sediment oxygen budget contributing about $1 \%$ of total oxygen consumption only. However, the continuous oxygen supply may ensure a persistent oxic environment for belowground tissues of $C$. rotundata and, hence, protect the plant from reduced phytotoxins.
\end{abstract}

KEY WORDS: Seagrasses - Roots - Sediments - Oxygen Respiration

The rhizosphere of submerged rooted plants is usually deprived of oxygen due to high respiration within the sediment and slow diffusion of oxygen from the water column to the sediment. Below-ground plant tissues may function temporarily on anaerobic metabolism, but the energy yield is 10 -fold lower than by aerobic respiration, and oxic conditions must be restored within hours for root and rhizome survival (Vartapetian \& Jackson 1997). All higher plants living in reduced soils and sediment, therefore, depend on efficient oxygen transport from above-ground tissues to rhizomes and roots.

•E-mail: olep@ibm.net
Part of the oxygen transported to roots and rhizomes escapes from the plant and diffuses into the rhizosphere (Armstrong et al. 1994), and this oxygen loss varies substantially among aquatic macrophytes (Sand-Jensen et al. 1982, Caffrey \& Kemp 1991). Freshwater species of isoetids in particular lose a large fraction of the photosynthetically generated oxygen to the sediment, where it may create oxic horizons with distinct diurnal oxygen fluctuations within the sediment (Christensen et al. 1994, Pedersen et al. 1995). The root oxygen loss in seagrasses has only been examined for eelgrass and it appears to be much lower than that in isoetids (Sand-Jensen et al. 1982, Caffrey $\&$ Kemp 1991). The low oxygen release will most likely generate oxic microzones around roots and rhizomes, as Caffrey \& Kemp (1991) reported for Potamogeton perfoliatus. Still this modest oxygen release may suffice to protect the plant from anaerobic phytotoxins in the sediment and to promote the aerobic degradation of organic matter within the rhizosphere.

In the present study we used microelectrode techniques to describe steady state oxygen profiles around roots of the tropical seagrass Cymodocea rotundata both in the light and in the darkness. The rates of oxygen loss were computed from the profiles and we provide an approximate estimate of diurnal oxygen flux from the roots to the sediment of a Philippine seagrass bed. We also describe the time course of oxygen release switching between light and dark conditions in order to assess the dynamic nature of rhizosphere oxygen conditions and to evaluate whether oxygen diffusion within the seagrass is based upon gas- or liquidphase diffusion in the lacunal tissues.

Material and methods. Shoots of Cymodocea rotundata were collected from a silty location at Santa Barbara, Bolinao in the Philippines (Terrados et al. 1998). The shoots were gently washed to remove the sediment and subsequently divided into 10 to $20 \mathrm{~cm}$ long 
rhizome fragments containing 2 to 5 ramets. The shoots were planted into $1 \mathrm{l}$ transparent glass beakers containing homogenised silty sediment from Santa Barbara, and some of the roots were carefully arranged horizontally towards the glass wall. The beakers were thereafter wrapped with aluminium foil and kept for $48 \mathrm{~h}$ in a large outdoor concrete pool, which was continuously flushed with fresh seawater, to allow reestablishment of the chemical profiles around the roots. All measurements were carried out under natural light ( 200 to $400 \mu \mathrm{mol}$ photons $\mathrm{m}^{-2} \mathrm{~s}^{-1}$ ) and constant temperature $\left(30^{\circ} \mathrm{C}\right)$.

Mapping of free oxygen in the rhizosphere was carried out using commercially available Clark-type microelectrodes (Unisense, Denmark). The microelectrode is small (tip diameter of $<10 \mu \mathrm{m}$ ), fast responding (90\% response $<1$ s), with a stirring sensitivity of $<1 \%$, and the tip of the electrode was extraordinarily thin to provide optimal flexibility. This allowed a set-up, where the flexible oxygen microelectrode was moved vertically with a micromanipulator (Märzhäuser, Germany) in steps of $10 \mu \mathrm{m}$ towards the root surface. Determination of the position of the root surface was made partly by visual inspection through the glass beaker by means of a dissection microscope (Olympus, Japan) and partly from the electrode signal (Revsbech et al. 1998a)

Dynamic time traces of the oxygen concentration at the root surface were obtained during steady state in light, during switches from light to darkness and during steady state in darkness. The microelectrode was positioned at the root surface and the signal from the electrode was logged on a datalogger (PicoLog, England) connected to the picoammeter (Unisense, Denmark). Steady state conditions were allowed to develop in light, after which the aquarium was covered with aluminium foil and steady state oxygen concentrations developed in darkness. Finally, the aluminium foil was removed to reestablish steady state light conditions.

The oxygen flux under steady state conditions in light and darkness was calculated from the cylindrical version of Fick's first law:

$$
J=D \frac{\mathrm{d} C}{\mathrm{~d} r} 2 \pi r
$$

where $J$ is the radial flux, $D$ is the effective diffusion coefficient, $\mathrm{d} C / \mathrm{d} r$ is the radial concentration gradient and $r$ is the radius of the root.

Results. The steady state oxygen profiles around the roots of Cymodocea rotundata showed the presence of a thin but nevertheless permanent oxic microzone (Fig. 1). In light, the root surface oxygen concentration was $75 \%$ of air saturation but it decreased dramatically to reach anoxic conditions only $80 \mu \mathrm{m}$ away from the

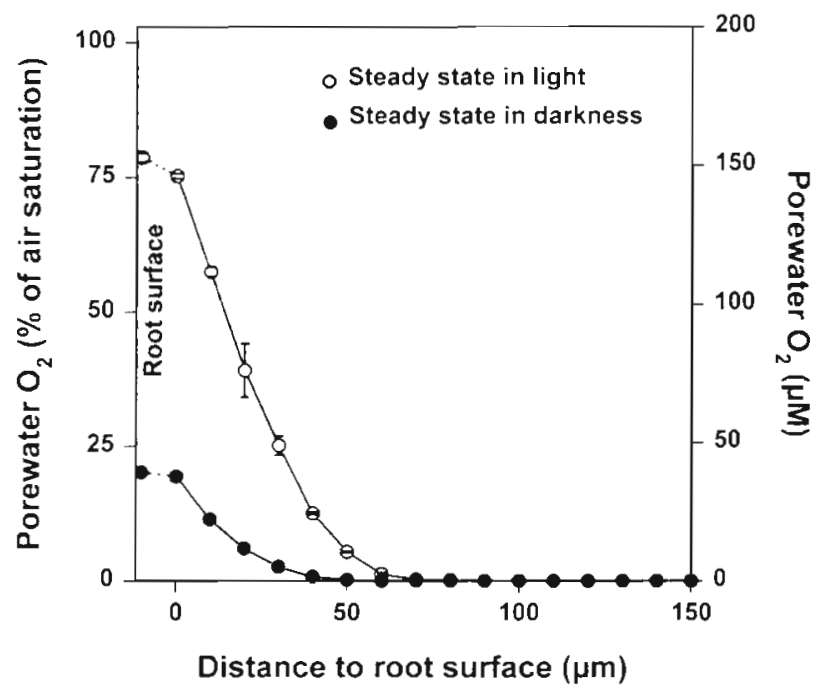

Fig. 1. Steady state microdistribution of porewater $\mathrm{O}_{2}$ versus distance to the root surface in Cymodocea rotundata. Steady state conditions were defined from the time trace of Fig. 3. (O) Light values, ( ) dark values. The measurements were repeated 3 times by withdrawing the microelectrode, moving it $200 \mu \mathrm{m}$ along the root axis and repeating the profiling. Mean values $\pm \mathrm{SD}$

root surface. In darkness, the oxygen concentration was $20 \%$ of air saturation at the root surface and the thickness of the oxic zone declined to $50 \mu \mathrm{m}$. Hence, the oxic microzone persisted although the oxygen supply from shoot photosynthesis ceased. The dotted line in Fig. 1 indicates the relative uncertainty associated with the determination of the actual root surface, i.e. the data point measured at the root surface may be displaced $\pm 5 \mu \mathrm{m}$ at the horizontal axis. Repeated measurements in more sandy sediments showed no difference from the measurements in silty sediments with respect to the thickness of the oxic zone (data not shown).

The oxygen flux from the root into the sediment was calculated from Eq. (1). Microscopic examination of the root (Fig. 2) showed an almost circular cross-section with a radius of $0.05 \mathrm{~cm}$. Hence, we treated the root as a hollow cylinder when calculating oxygen fluxes. The effective diffusion coefficient of silty sediments has previously been determined to be $1.4 \times 10^{-5} \mathrm{~cm}^{2} \mathrm{~s}^{-1}$ by Revsbech et al. (1998a, b). The concentration gradient $(\mathrm{d} C / \mathrm{d} r)$ was calculated from the slope of the linear parts of Fig. 1 to be 33.1 in light and $13.2 \mathrm{nmol} \mathrm{O}_{2} \mathrm{~cm}^{-4}$ in darkness. Accordingly, the oxygen flux was calculated to be $5.25 \mu \mathrm{mol} \mathrm{O} \mathrm{m}^{-2}$ root $\mathrm{h}^{-1}$ in light and to be $2.28 \mu \mathrm{mol} \mathrm{O}_{2} \mathrm{~m}^{-2}$ root $\mathrm{h}^{-1}$ in darkness. Assuming $12 \mathrm{~h}$ light and $12 \mathrm{~h}$ darkness, the $24 \mathrm{~h}$ estimate amounts to $90.28 \mu \mathrm{mol} \mathrm{O} \mathrm{O}^{-2}$ root $\mathrm{d}^{-1}$. If we correct for the actual root surface in a typical mixed seagrass bed of the Philippines $10.95 \mathrm{~m}^{2}$ root $\mathrm{m}^{-2}$ sediment; Duarte et al. 
1998), the root-mediated oxygen loss amounted to about $85.8 \mu \mathrm{mol} \mathrm{O}_{2} \mathrm{~m}^{-2}$ seagrass bed $\mathrm{d}^{-1}$ or down to $10.8 \mu \mathrm{mol} \mathrm{O}_{2}$ $\mathrm{m}^{-2}$ seagrass bed $\mathrm{d}^{-1}$ if the root contribution of only Cymodocea rotundata is taken into account $\left(0.12 \mathrm{~m}^{2}\right.$ root $\mathrm{m}^{-2}$ sediment; Duarte et al. 1998).

The oxygen concentration at the root surface responded rapidly to changes in light conditions (Fig. 3). It took less than $1.5 \mathrm{~h}$ to reach a new steady state after switching from darkness to light and the changes from light to darkness were equally fast. These measurements also showed that oxic conditions persist at the root surface under darkness.

We can obtain a rough idea of the permeability of the transport pathway from leaves to roots by modelling the time trace obtained from Fig. 3 (Revsbech \& Jørgensen 1986). We applied the 1dimensional version of Fick's second law of diffusion, assuming an indefinitely long root and an instantaneous change from 75 to $25 \%$ of air saturation at the source (the lacunae within the leaves) upon switching from light to darkness. In addition, we assumed that the whole pathway from leaves to roots may be gas-phase diffusion and only the last part from the root lacunae and out through the root cortex to the tip of the electrode would be liquid-phase (225 $\mu \mathrm{m}$; Fig. 2). The time trace in Fig. 3 was obtained 5.5 $\mathrm{cm}$ from the leaf base and it showed a $50 \%$ decrease of the total decline in oxygen after $28 \mathrm{~min}$. The model predicted a $50 \%$ decrease after $28 \mathrm{~min}$ to occur 7.8 $\mathrm{cm}$ from the source, or close to the actual $5.5 \mathrm{~cm}$.

Discussion. These results provide the first experimental description of the microdistribution of free oxygen around roots of a seagrass. The oxygen concentration at the root surface of Cymodocea rotundata was relatively high (about
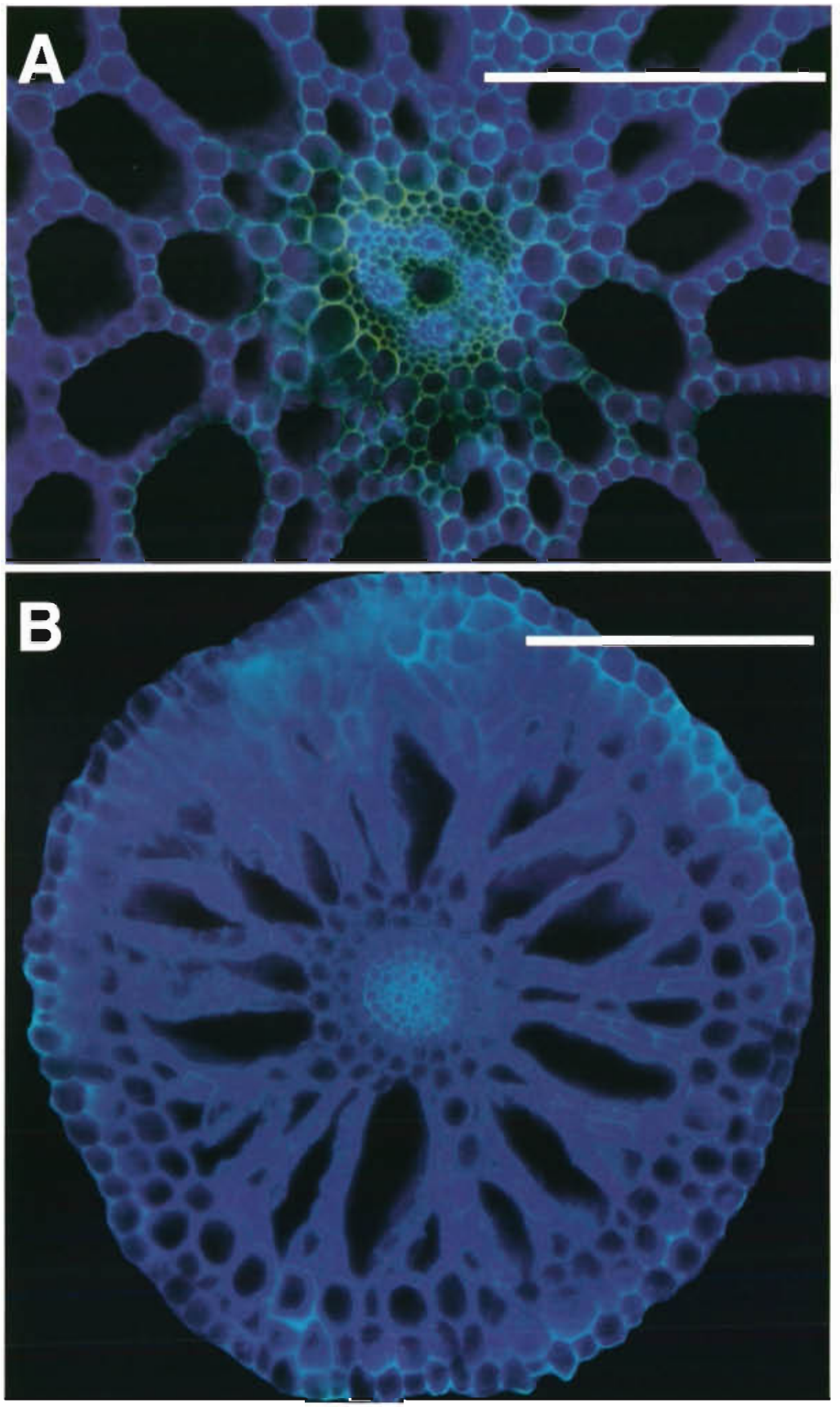

Fig. 2. Transversal sections of (A) the rhizome and (B) the root of Cymodocea rotundata. The tissue was stained in Calcofluor White and examined by epifluorescence microscopy. $\mathrm{Bar}=500 \mu \mathrm{m}$

$75 \%$ of air saturation in light) but rapid

oxygen consumption of the silty sediment resulted in steep gradients and confined the thickness of the oxic microzones to $80 \mu \mathrm{m}$. This is considerably less than the $350 \mu \mathrm{m}$ microzone found for roots of rice in waterlogged soil (Revsbech et al. 1998a) and the several $\mathrm{mm}$ thick oxic zone measured around rhizomes of Potamogeton pectinatus (Caffrey \& Kemp 1991). The oxygen loss from $C$. rotundata was, furthermore, much lower than the oxygen loss from roots of the freshwater isoetids, Littorella uniflora (Christensen et al. 1994) and Lobelia dortmanna (Pedersen et al. 1995), which create extensive oxic horizons within the sediment. However, these latter species are especially adapted to facilitate gas exchange with the sediment since porewater $\mathrm{CO}_{2}$ is their main inorganic carbon source for photosynthesis (Pedersen \& Sand-Jensen 1992). The 


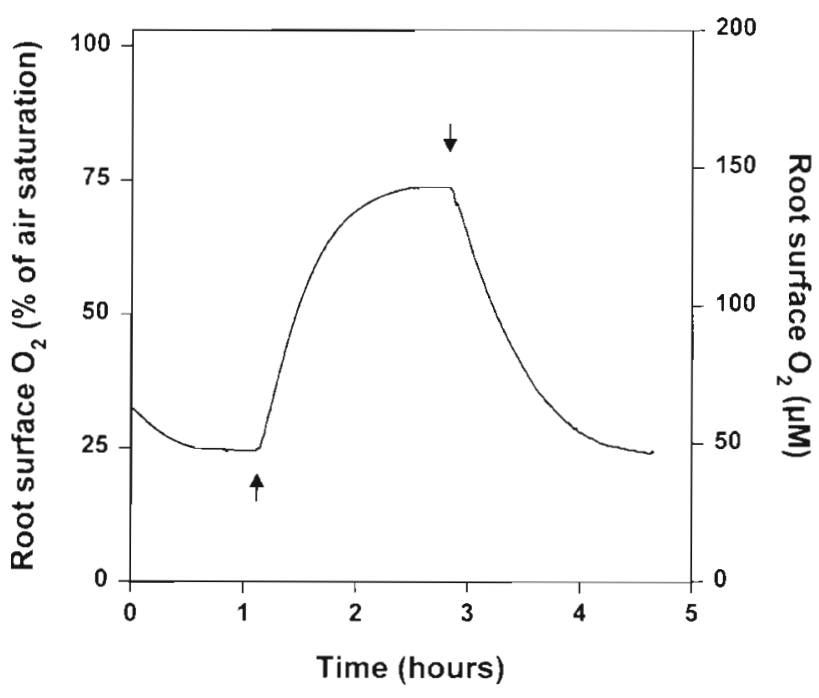

Fig. 3. Time trace of the oxygen concentration on the root surface of Cymodocea rotundata in a dark-light-dark cycle. The arrows denote the time at which the steady state microdistribution profiles for Fig. 1 were obtained

modest rates of root oxygen loss found for $C$. rotundata (this study) and for Zostera marina (Sand-Jensen et al. 1982) suggest that seagrasses may, in general, leak less oxygen to the sediment than rooted freshwater macrophytes.

The finding of free oxygen in the seagrass rhizosphere agrees with the observations by Oremland \& Taylor (1977) who detected diel changes of oxygen concentrations in gas bubbles from the sediment of a Thalassia testudinum bed. Although some studies have failed to detect free oxygen in the rhizosphere of Zostera noltii and Z. marina (citations in RisgaardPetersen \& Jensen 1997), we suggest that oxic microzones around roots of seagrasses must be present, in general, at least when the plants are illuminated. If aerobic respiration is to be maintained in the outer root epidermis cells, then some leakage of oxygen to the surrounding medium must occur to give rise to an oxygen containing rhizosphere. The well-developed aerenchyma of Cymodocea rotundata rhizomes and roots (Fig. 2) allows the plant to efficiently support the root cells with oxygen for aerobic respiration and similar aerenchyma have been found in other seagrasses (Barnabas 1987, 1991).

We did not expect, however, that the oxygen release from the roots of Cymodocea rotundata would be maintained during darkness. The oxic microzone clearly shrank and the oxygen concentration at the root surface declined to about $20 \%$ of air saturation at steady state, but the persistent oxygen profiles document that $C$. rotundata was able to sustain an efficient oxygen supply to the roots also in darkness. This oxygen cannot have been supplied by leaf photosynthesis.
The steep decline in Fig. 3 indicates that the photosynthetic oxygen pool present within the aerenchyma may supply respiration and oxygen leakage to the sediment for less than $2 \mathrm{~h}$ before a new steady state is reached. Under the steady state condition, respiration and the root-mediated oxygen loss to the sediment must be supplied by constant rate diffusion, where oxygen diffuses from the water surrounding the leaves, into the leaf lacunae and down to the roots via the aerenchyma. As verified by the modelling of the diffusive pathway, the transport must primarily occur as gas-phase diffusion with only a few barriers of liquid-phase diffusion between the leaf and the root surface. This pathway allows for the rapidly attained steady states (less than $1.5 \mathrm{~h}$ ) upon switching between dark and light and for the continuous oxygen supply of roots in the dark. According to Smith et al. (1984) the oxygen supply for aerobic respiration in roots of Zostera marina derives from leaf photosynthesis, and root metabolism switches to anaerobic respiration after a few hours in darkness. This was obviously not the case for $C$. rotundata, and we suggest that other seagrass species with similar morphology and moderate distances between above- and below-ground tissues may also supply aerobic root respiration by passive diffusion of oxygen from leaves to roots during the night.

The importance of root-mediated oxygen leakage by seagrasses for total aerobic decomposition in the sediment is likely small. The sediment consumption of oxygen may amount to $20-131 \mathrm{mmol} \mathrm{O}_{2} \mathrm{~m}^{-2} \mathrm{~d}^{-1}$ (Blackburn et al. 1994), which is more than 200-fold higher than our rough estimate of total oxygen supply via roots $\left(0.085 \mathrm{mmol} \mathrm{O}_{2} \mathrm{~m}^{-2} \mathrm{~d}^{-1}\right)$ in the Philippine seagrass bed. Although the total seagrass root surface may be large, the sediment volume kept oxic by root oxygen leakage is probably modest. If we assume a mean root diameter of $1 \mathrm{~mm}$ and a constant oxic microzone around all roots of $80 \mu \mathrm{m}$, less than $100 \mathrm{~cm}^{3}$ (equivalent to $0.5 \%$ ) of the sediment would be kept oxic per $\mathrm{m}^{2}$ of our mixed seagrass bed containing $0.95 \mathrm{~m}^{2}$ root surface. Some aerobic microbial processes may, however, rely primarily on the root-mediated oxygen leakage because the roots are excreting organic carbon, which may stimulate specific bacteria (Hough \& Wetzel 1975). Sediment processes confined to the oxic-anoxic interphase (e.g. coupled nitrification-denitrification) may also be stimulated by oxygen leakage from the roots of submerged macrophytes (Christensen \& Sørensen 1986, Caffrey \& Kemp 1992, Risgaard-Petersen \& Jensen 1997). Moreover, the permanent oxidized rhizosphere is probably of vital importance for the plant in detoxifying reduced phytotoxins (e.g. sulphide) in the near-root sediment (Penhale \& Wetzel 1983, van Wijck et al. 1992, Carlson et al. 1994, Goodman et al. 1995). 
Our findings point towards several important aspects that remain subjects for critical examination. For example, we expect that there are considerable oxygen gradients along the axis of the seagrass roots as found for both maize (Armstrong et al. 1994) and rice (Revsbech et al. 1998a). Also, it has been shown that the longitudinal oxygen permeability varies from the base of the root towards the tip with large permeability near the root tip (Armstrong 1971, Smirnoff \& Crawford 1983, Armstrong \& Armstrong 1988, Koncalova 1990, Smits et al. 1990). This phenomenon is probably of high adaptive value since it enhances the diffusion to the root tip and thus allows greater penetration of roots into anaerobic sediments. We cannot exclude, however, that distal parts of the Cymodocea rotundata roots may be forced into anaerobic respiration during unfavourable conditions. Also, we do not know whether the measured oxygen leakage applies to all age stages of the roots. Christensen et al. (1994) present data suggesting those young roots of Littorella uniflora leak more oxygen than old roots. Finally, the oxygen dynamics of the rhizosphere of $C$. rotundata may greatly depend on rates of plant respiration and sediment oxygen consumption.

In summary, we have documented the permanent presence of microzones with free oxygen around roots of Cymodocea rotundata. During darkness the oxygen is not derived from leaf photosynthesis but rather from the large oxygen pool of the water column. The rootmediated oxygen leakage seems unimportant for the total aerobic metabolism in the sediment but it may be vital for root-associated microbial processes and for detoxifying reduced phytotoxins in the sediment.

Acknowledgement. This research was funded by the STD-III programme of the European Commission (project TS3*CT94-0301). This is a contribution to the LOICZ program (project \#27), a core project of the IGBP program. We thank C. Day Lacap for assistance.

\section{LITERATURE CITED}

Armstrong J, Armstrong W (1988) Phragmites australis-a preliminary study of soil-oxidizing sites and internal gas transport pathways. New Phytol 108:373-382

Armstrong $W$ (1971) Radial oxygen losses from intact rice roots as affected by distance from the apex, respiration and waterlogging. Physiol Plant 25:192-197

Armstrong W, Strange ME, Cringle S, Beckett, PM (1994) Microelectrode and modelling study of oxygen distribution in roots. Ann Bot 74:287-299

Barnabas A (1987) Zostera capensis Setchell: root structure in relation to function. Aquat Bot 27:309-322

Barnabas A (1991) Thalassodendron ciliatum (Forssk.) Den Hartog: root structure and histochemistry in relation to apoplastic transport. Aquat Bot 27:309-322

Blackburn TH, Nedwell DB, Wiebe WJ (1994) Active mineral cycling in a Jamaican seagrass sediment. Mar Ecol Prog Ser $110: 233-239$
Caffrey JM, Kemp WM (1991) Seasonal and spatial patterns of oxygen production, respiration and root-rhizome release in Potamogeton perfoliatus L. and Zostera marina L. Aquat Bot 40:109-128

Caffrey JM, Kemp WM (1992) Influence of the submerged plant, Potamogeton perfoliatus, on nitrogen cycling in estuarine sediments. Limnol Oceanogr 37:1483-1495

Carlson PR, Yabro LA, Barber TR (1994) Relationship of sediment sulphide to mortality of Thalassia testudinum in Florida Bay. Bull Mar Sci 54:733-746

Christensen PB, Revsbech NP, Sand-Jensen K (1994) Microsensor analysis of oxygen in the rhizosphere of the aquatic macrophyte Littorella uniflora (L.) Ascherson. Plant Physiol 105:847-852

Christensen PB, Sørensen J (1986) Temporal variation of denitrification activity in plant-covered littoral sediment from Lake Hampen, Denmark. Appl Environ Microbiol 51: $1174-1179$

Duarte CM, Merino M, Agawin NSR, Uri J, Fortes MD, Gallegos ME, Marbá N, Hemminga MA (1998) Root production and belowground seagrass biomass. Mar Biol (in press)

Goodman JL, Moore KA, Dennison WC (1995) Photosynthetic responses of eelgrass (Zostera marina L.) to light and sediment sulphide in a shallow barrier island lagoon. Aquat Bot 50:37-47

Hough RA, Wetzel RG (1975) The release of dissolved organic carbon from submersed aquatic macrophytes: diel, seasonal, and community relationships. Int Ver Theor Angew Limnol Verh 19:939-948

Koncalova H (1990) Anatomical adaptations to waterlogging in roots of wetland graminoids: limitations and drawbacks. Aquat Bot 38:127-134

Oremland RS, Taylor BF (1977) Diurnal fluctuations of $\mathrm{O}_{2}, \mathrm{~N}_{2}$, and $\mathrm{CH}_{4}$ in the rhizosphere of Thalassia testudinum. Limnol Oceanogr 22:566-570

Pedersen O, Sand-Jensen K (1992) Adaptations of submerged Lobelia dortmanna to aenal life form: morphology, carbon sources and oxygen dynamics. Oikos 65:89-96

Pedersen O, Sand-Jensen K, Revsbech NP (1995) Diel pulses of $\mathrm{O}_{2}$ and $\mathrm{CO}_{2}$ in sandy lake sediments inhabited by Lobelia dortmanna. Ecology 76:1536-1545

Penhale PA, Wetzel RG (1983) Structural and functional adaptations of eelgrass (Zostera marina L.) to the anaerobic sediment environment. Can J Bot 61:1421-1428

Revsbech NP, Jørgensen BB (1986) Microelectrodes: their use in microbial ecology. Adv Microb Ecol 9:293-352

Revsbech NP, Nielsen LP, Ramsing NB (1998b) A novel microsensor for the determination of diffusivity in sediments and biofilms. Limnol Oceanogr (in press)

Revsbech NP, Pedersen O, Reichardt. W, Briones A (1998a) Microsensor analysis of oxygen and $\mathrm{pH}$ in the rice rhizosphere under field and laboratory conditions. Biol Fertil Soils (in press)

Risgaard-Petersen N, Jensen K (1997) Nitrification and denitrification in the rhizosphere of the aquatic macrophyte Lobelia dortmanna L. Limnol Oceanogr 42:529-537

Sand-Jensen K, Prahl C, Stokholm H (1982) Oxygen release from roots of submerged aquatic macrophytes. Oikos 38 : 349-354

Smirnoff N, Crawford RMM (1983) Variation in the structure and response to flooding of root aerenchyma in some wetland plants. Ann Bot 51:237-249

Smith RD, Dennison WC, Alberte RS (1984) Role of seagrass photosynthesis in root aerobic processes. Plant Physiol 74 : 1055-1058

Smits AJM, Laan P, Thier RH, vand der Velde G (1990) Root 
aerenchyma, oxygen leakage patterns and alcoholic fermentation ability of the roots of some nymphaeid and isoetid macrophytes in relation to the sediment type of their habitat. Aquat Bot 38:3-17

Terrados J, Duarte CM, Fortes MD, Borum J, Agawin NSR, Bach S, Thampanya U, Kamp-Nielsen L, Kenworthy WJ, Geertz-Hansen O, Vermat J (1998) Changes in community structure and biomass of seagrass communities along

Editorial responsibility: Otto Kinne (Editor), Oldendorf/Luhe, Germany gradients of siltation in SE Asia. Estuar Coast Shelf Sci (in press)

van Wijck C, de Groot CJ, Grillas P (1992) The effect of anaerobic sediment on the growth of Potamogeton pectinatus L.: the role of organic matter, sulphide and ferrous iron. Aquat Bot $44: 31-49$

Vartapetian BB, Jackson MB (1997) Plant adaptations to anaerobic stress. Ann Bot 79(suppl A):3-20

Submitted: March 3, 1998; Accepted: June 20, 1998 Proofs received from author(s): July 24, 1998 